\title{
The Importance of Creative Knowledge Workers in Creative Organization
}

\author{
Aneta Sokół ${ }^{1, *}$ and Irena Figurska ${ }^{2}$ (D) \\ 1 Institute of Management, Faculty of Economics, Finance and Management, University of Szczecin, \\ Cukrowa 8, 71-004 Szczecin, Poland \\ 2 Institute of Safety and Management, Pomeranian University in Slupsk, Arciszewskiego 22A, \\ 76-200 Slupsk, Poland; irenafigurska@vp.pl \\ * Correspondence: aneta.dorota@wp.pl or aneta.sokol@usz.edu.pl
}

check for updates

Citation: Sokół, A.; Figurska, I. The Importance of Creative Knowledge Workers in Creative Organization. Energies 2021, 14, 6751. https:// doi.org/10.3390/en14206751

Academic Editor:

Jurgita Raudeliuniene

Received: 30 June 2021

Accepted: 13 October 2021

Published: 16 October 202

Publisher's Note: MDPI stays neutral with regard to jurisdictional claims in published maps and institutional affiliations.

Copyright: (c) 2021 by the authors. Licensee MDPI, Basel, Switzerland. This article is an open access article distributed under the terms and conditions of the Creative Commons Attribution (CC BY) license (https:// creativecommons.org/licenses/by/ $4.0 /)$.

\begin{abstract}
The growing importance of creative knowledge workers as a resource of particular significance for the growth of organizations is becoming one of the greatest challenges of the knowledgebased economy. Thus, the growing role of creative organizations contributes to building the economic potential of cities, regions, countries, but also of various organizations operating in the market. The development of civilization at its current stage has always been a source of this type of activity. Hence, the issue of understanding how creative knowledge workers operate has been and continues to be addressed by researchers around the world in recent years. The topic presented in this article on the knowledge and creativity of employees and their impact on the growth of creative organizations to a certain extent responds to this demand. The aim of the article is to clarify and extend the conceptualization in terms of creative activities performed by knowledge workers and the correlations with their characteristics and with knowledge initiatives. Achieving the set aim would allow to indicate that modern development depends on the proper generation of knowledge and creativity and the resources offered by an organization to facilitate its absorption in terms of growth prospects. The article reviews the research on cognitive, theoretical, methodological, and empirical issues regarding the development of creative knowledge workers employed in creative organizations as well as characteristics of workers and knowledge initiatives introduced in organizations. The analysis of the literature allowed to establish a research framework and indicate which knowledge initiatives are important and which characteristics of selected employees may be related to creative activities. Empirical verification was carried out through the analysis of basic descriptive statistics with Spearman's $\rho$ rank correlation and the relationship between nominal and ordinal variables using chi-square tests. The results of the study revealed significant relationships between the performance of creative activities and certain characteristics of knowledge workers as well as between the performance of creative activities and the introduction of knowledge initiatives. It turned out that the knowledge of the nature of the connections between the mentioned activities and knowledge initiatives is the basis for determining which knowledge initiatives in the case of a given creative organization will bring the best results in the form of taking effective creative activities by knowledge workers. Moreover, a person who performs creative activities has only some of the characteristics presented in this article. The research results are particularly relevant to the development of creative knowledge workers employed in creative organizations. Setting out guidelines aimed at changing this state of affairs and the research conducted allowed the identification of areas for improvement in order to ensure that they develop more effectively and meet the demands of competitiveness, generating more innovative ideas.
\end{abstract}

Keywords: creative organization; knowledge worker; creativity

\section{Introduction}

In recent years, the approach to the issue of creativity in management has changed fundamentally. It is now argued that no matter how much knowledge one has, what 
matters is the ability to process and apply it creatively. Therefore, a special role is assigned to demographic and socio-cultural factors as significant determinants of the creative organization's growth [1]. For this reason, both theoreticians and practitioners agree on the role of creativity and knowledge as a source of business organizations' growth, which is discussed in this article [2-7]. This applies to all organizations, albeit to a different extent. The success of organizations operating in the creative sectors depends to a greater extent on the proper management of knowledge and creativity than in industries where the competitive advantage is determined primarily by the skillful use of classic production factors [1,8-25]. However, previous studies of the authors indicate that the actions taken in organizations regarding knowledge and creativity management are often undertaken rather intuitively than on the basis of knowledge, which does not bring the expected results and discourages managers from further applying these concepts in practice. The reason for this is often insufficient knowledge about the above-mentioned concepts of management, including, among others, about knowledge initiatives and their connection with the undertaking of creative activities by knowledge workers, who today, in the knowledge-based economy, constitute the greatest wealth of the organization and the fundamental determinant of their competitiveness. Moreover, although it is commonly believed that the increase in employees' knowledge is conducive to their creativity (due to the fact that as a result of the development of knowledge, the possibilities of unique combination of new knowledge with the existing knowledge of the employee increase, which may result in the emergence of new ideas), there is a research gap in the area of identifying interrelationships between knowledge initiatives and creative activities, as well as between the characteristics of creative knowledge workers and creative activities. This research gap has become the basis for determining the goal of the article, which is to explain and extend the conceptualization in the field of creative activities performed by the surveyed creative knowledge workers and the relationships of these activities with knowledge workers' characteristics and knowledge initiatives. To achieve this goal, the following research questions were formulated: Is there a correlation between specific creative activities and characteristics of creative knowledge workers? Is there a correlation between specific creative activities and knowledge initiatives? The structure and content of the article have been designed in such a way that it is possible to answer the research questions.

The first part of the article focuses on the analysis of the source literature. The study investigated foreign and Polish literature which provided the basis for the critical analysis and the research framework. It concerned the development of the concept of creative organizations and the role of creative knowledge workers.

The second part of the article focuses on the research conducted using an original questionnaire which included questions about the applied knowledge initiatives, creative activities undertaken, and the characteristics of creative knowledge workers The obtained data made it possible to determine the relationships between: knowledge initiatives and creative activities as well as the characteristics of knowledge workers and the use of creative activities. The research was conducted using Spearman's correlation and the strength of relationship between nominal and ordinal variables was measured using chi-square tests.

Conclusions from the literature studies and from the analysis of the results of the conducted research made it possible to answer the research questions. In addition, the article establishes a comprehensive theoretical framework for creative organizations in which the allocation of knowledge and creativity plays an important role.

This paper contributes to the development of management theory (e.g., through the proprietary models presented in Sections 1 and 2), but also has practical implications. By identifying the relationship between knowledge initiatives and creative activities, it helps managers make decisions regarding the implementation (or not) of specific knowledge initiatives depending on the strength of their influence on employees' creative activities. On the other hand, the search for the relationship between the selected characteristics of creative knowledge workers and creative activities allows for the appropriate selection of employees in creative organizations, so that their work can generate more creative activities. 


\section{Creative Organization-An Attempt at Conceptualization}

Creativity is a key factor in innovation, competitiveness, and better performance of an organization [2-7]. Creativity itself in an organization has no value until it is commercialized and translated into a specific product, service, or process offered to the customer. The results of the conducted research presented in the source literature revealed a statistically significant and direct relationship between organizational creativity and organizational effectiveness of a company and emphasized the role of creativity as a key capability of a company [26], highlighted creativity as a strategically valuable resource, and a crucial source of competitive advantage $[27,28]$. Furthermore, creativity has been identified as the key to sustainable competitive advantage for organizations [29] by one of the better known researchers on the subject-Amabile and her team [30]. It is also recognized that creativity has contributed to some of the most important innovations in human history and to solving some of our most complex and major problems [31].

According to the Sternberg's investment theory, creativity is a confluence of six distinct but interrelated resources: intellectual abilities, knowledge, styles of thinking, personality, motivation, and environment [32]. Therefore, when applying existing values, creativity may be considered the most effective method of adding value. This approach to creativity is particularly important when discussed in the context of organizations, as it means being able to do something new and useful (Figure 1) [33].

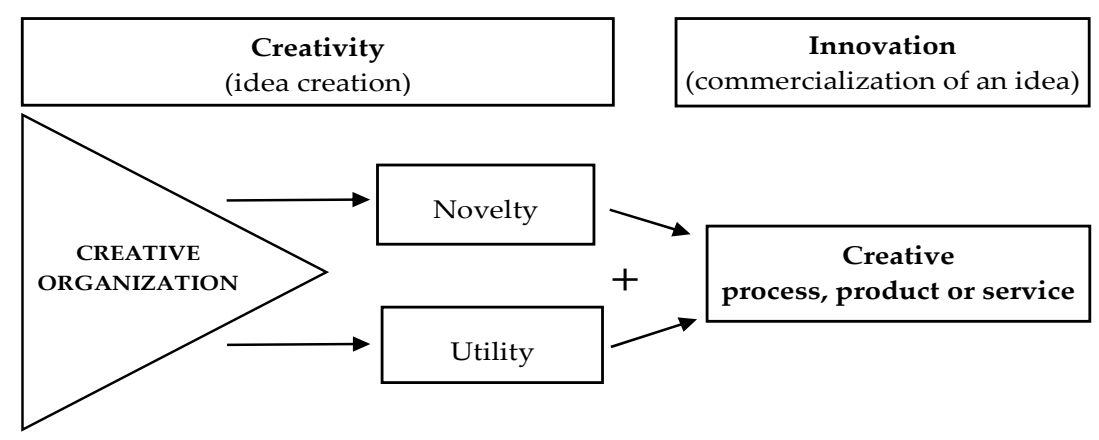

Figure 1. Interrelations between entrepreneurship, creativity, and innovation in a creative organization. Source: created by the authors.

The foundations of contemporary organizational creativity according to Zhou and Shalley [8] and Anderson, Potočnik, and Zhou [9] refer to Woodman, Sawyer, and Griffin's [10] interactionist model, Amabile's [11,12] componential model, and Ford's [13] model. The model of Woodman et al. [10] was one of the first to actually highlight the multi-level nature of organizational creativity and different influences that it has at different levels. The cited author divided these influences into three levels: individual (creative behavior, cognitive style/abilities, personality, knowledge, and intrinsic motivation), group (group composition, characteristics of a group and group processes, contextual influences), and organizational (organizational design and structure, communication channels and information flows). Amabile's $[11,14]$ componential model of creativity also links individual creativity (i.e., motivation, creative skills and expertise) to the work environment (organizational motivation to innovate, management practices and resources) and thus to organizational creativity. Ford [13], drawing inspiration from Csikszentmihalyi's $[15,16]$ systems model according to which creativity is developed through the dynamic action of "a system composed of three elements: a culture containing symbolic rules, a person who brings novelty to the domain and an expert domain", proposed a model of individual creative action (which results from a combination of meaning making, goals, motivation, knowledge, and ability as well as emotions and beliefs about sensitivity and ability connected with an individual's beliefs about their own capabilities related to creativity and tasks and potential reactions in this domain) that is influenced by multiple social domains [34].

Therefore, considering different research concepts and different ways of understanding them (cf. Table 1), modelling and defining a creative organization is difficult and 
ambiguous. It should be noted, however, that, referring to the definitions presented in the article, the more appropriate way to understand the phenomenon of creative organization is the analysis of their interpretation and its contextual character, in which it was and continues to be considered. The term creative organization refers to such aspects as: the ability of an organization to find new relationships and connections, a certain type of creating new relationships, the process of the emergence of new creative works, predisposition to perceive innovation, mind activity in the individual and organizational dimensions generating new discoveries, and a certain way of imagining new products, services or ideas. This is also due to the fact that the diversity in modes of operation of business entities in creative sectors demonstrates how different creative organizations can be from each other. Some are small entities of several employees (e.g., advertising companies), while others are large entities which need multi-task, complex organizational structures (e.g., research institutes, universities). Taking into account the aspects distinguished above, the article proposes the following definition of this term: a creative organization is an entity whose systemic activity is based on the utilization of tangible and intangible resources for the effective use of individual mental activities to merge them into collective processes, striving to achieve the creative process of a higher order at different levels of organization and management. The major resource determining the creative process in an organization is the proper potential of intellectual capital, including creatively active human capital. Such a company seeks to achieve a rapid growth in value, including competitiveness, with a view to accomplishing economic, social, cultural, and prestige objectives. Such entities produce copyrighted ideas, products, or creative services [1].

Table 1. The concept of organizational creativity—a review of selected source literature.

\begin{tabular}{|c|c|}
\hline Authors & Definitions \\
\hline Kao (1989) & $\begin{array}{l}\text { Creativity in an organizational context may be thought of as the sum of the following functions: } \\
\text { creative person, creative task and organizational context (culture). }\end{array}$ \\
\hline Amabile (1996) & $\begin{array}{l}\text { Creativity is the production of new and useful ideas by employees. The definition of creativity } \\
\text { includes two essential elements: a product or answer that will be considered creative to the extent } \\
\text { that (a) it is both new and appropriate, useful, correct or valuable, relevant (b) the task is heuristic } \\
\text { rather than algorithmic. }\end{array}$ \\
\hline Csikszentnihalyi (1990) & Creativity is not an attribute of individuals but of a social system that forms judgments about an individual \\
\hline Woodman et al. (1993) & $\begin{array}{l}\text { Organizational creativity is the production of a valuable, useful, new product, service, idea, } \\
\text { procedure or process by individuals working together in a complex social system. }\end{array}$ \\
\hline Oldham, Cunnings (1996) & $\begin{array}{l}\text { Creative work of an employee results in new and useful products, ideas and procedures that provide } \\
\text { an organization with an important resource for further refinement and possible implementation. }\end{array}$ \\
\hline Sternberg, Lubart (1999) & $\begin{array}{l}\text { Creativity is the ability to produce work that is novel (original and unexpected/surprising) and } \\
\text { valuable (i.e., adaptively useful in terms of task limitation). }\end{array}$ \\
\hline Ford, Goia (2000) & $\begin{array}{l}\text { Creativity is not an attribute of a product but a judgement about its level of novelty and value made } \\
\text { by the most important persons in a particular field. }\end{array}$ \\
\hline Zhou, George (2001) & $\begin{array}{l}\text { Creativity in an organizational context means producing new potentially useful ideas. An idea is } \\
\text { considered creative when it is both new and useful. }\end{array}$ \\
\hline Martins, Terblanche (2003) & $\begin{array}{l}\text { The concept of creativity may be defined as the production of new and useful, valuable ideas } \\
\text { regarding products, services, procedures, processes by individuals or groups of individuals in a } \\
\text { specific organizational context. }\end{array}$ \\
\hline Choi et al. (2010) & $\begin{array}{l}\text { Creativity in organizations has been defined as the development of new and potentially useful } \\
\text { products, processes or solutions. }\end{array}$ \\
\hline Munfard et al. (2011) & $\begin{array}{l}\text { Creativity means the production of original, useful and neat solutions to problems that are novel, } \\
\text { complex or have an ill-defined structure. }\end{array}$ \\
\hline Basadur et al. (2012) & $\begin{array}{l}\text { Organizational creativity is the system of knowledge, process and skills needed for the execution of } \\
\text { the work process, tools and appreciation of differences in process execution style. }\end{array}$ \\
\hline Zhou, Ren (2012) & $\begin{array}{l}\text { Organizational creativity is related to the production of new and useful ideas about products, } \\
\text { services, processes, practices, managers, business models and competitive strategies. }\end{array}$ \\
\hline Bratnicka, (2014) & $\begin{array}{l}\text { "Organizational creativity is defined as the ability of an organization to simultaneously generate both } \\
\text { new and useful ideas, resulting from hosting multiple contradictory structures and processes within } \\
\text { the same organization." }\end{array}$ \\
\hline
\end{tabular}

Source: [10,12,35-46]. 
The functioning of a creative organization consists of numerous co-existing and interrelated factors. Researchers of the phenomenon refer to the role of creative resources (employees and creative teams), including their knowledge, to creative leaders, the creative environment of an organization, including the proper coherent management of creativity and knowledge. It should be emphasized, though, that these two aspects are inseparable as the novelty usually builds on the old and numerous useful innovations would not have been developed if it were not for specialized knowledge [1,41,47-54]. According to the results of the research, a team of employees in a creative organization should consist not only of experts [55]. Individuals with experience and professional knowledge are highly desirable members of creative organizations and contribute greatly to the achievement of goals set. However, research demonstrates that the work of creative organizations relies primarily on individuals with high knowledge absorptive capacity, as it is this capacity that allows new creative ideas to be produced [56]. As nowadays even unrelated disciplines sometimes work together to create novelties, teams should be composed of members with diverse domain knowledge.

\section{Creative Knowledge Workers}

Creativity is a key factor in innovation, competitiveness, and better performance of an organization [2]. Creative knowledge workers are one of the most important resources of a creative organization operating in the knowledge-based economy [17-25]. The term knowledge worker was introduced to the language of management science and practice several decades ago, however no universal and commonly accepted definition of knowledge worker has been developed yet. Most often knowledge workers are defined through the prism of their characteristics, level of education, actions taken, knowledge, experience, etc., as well as through the prism of the requirements placed on them by the organization. Table 2 presents selected definitions of knowledge workers demonstrating different perspectives of their authors.

Table 2. Definitions of knowledge workers.

\begin{tabular}{|c|c|}
\hline Authors & Knowledge Workers Are People ... \\
\hline (Drucker 1957) & who possess, utilise and create valuable knowledge \\
\hline (Davenport, 2005) & $\begin{array}{l}\text { who "have high degrees of expertise, education or experience, and the primary purpose of their jobs } \\
\text { involves the creation distribution, or application of knowledge" }\end{array}$ \\
\hline (Nickols, 2012) & who work not only with knowledge and information, but also on them \\
\hline (Gurteen, 2006) & $\begin{array}{l}\text { "who have taken responsibility for their work lives. They continually strive to understand the world } \\
\text { about them and modify their work practices and behaviours to better meet their personal and } \\
\text { organisational objectives. No one tells them what to do. They do not take 'no' for an answer. They } \\
\text { are self-motivated" }\end{array}$ \\
\hline (Morawski, 2003) & $\begin{array}{l}\text { who have unique skills as well as are: specialized in their profession, well-informed, active and } \\
\text { responsible, aware of their role and their self-worth, independent participants of the organization }\end{array}$ \\
\hline $\begin{array}{l}\text { (Skrzypek, 2009) } \\
\text { (Morello Caldwell 2001) }\end{array}$ & who are paid for efficiency of thinking, and whose minds are regarded as the primary work tools \\
\hline (Serrat, 2008) & $\begin{array}{l}\text { who are employed because of their knowledge of a subject matter, rather than ability to perform } \\
\text { manual labor. They perform best when empowered to make the most of their deepest skills }\end{array}$ \\
\hline $\begin{array}{l}\text { (Nicholas, 2019) } \\
\text { (Rosenthal-Sabroux, } \\
\text { Grundstein, Iafrate, 2008) }\end{array}$ & $\begin{array}{l}\text { are: researchers, planners, analysts and/or developers who acquire, manipulate, and analyze information } \\
\text { whose job depends on the processing and use of knowledge and information in work situations that } \\
\text { require decision making, and demand their initiative and responsibilities }\end{array}$ \\
\hline (Surawski, 2019) & $\begin{array}{l}\text { who perform knowledge-rich jobs. Such workers are typically but not universally well educated. } \\
\text { who "work mainly on symbols (representations), transforming them in cognitive processes, which is } \\
\text { the main source of added value. To do that, they must command a large body of knowledge } \\
\text { equivalent to university education, understood and internalised, grounded in experience and } \\
\text { consequently updated. They perform complex tasks, focus on problem-solving, creating knowledge, } \\
\text { distributing it and applying to achieve results. They broadly use documents and ICT, and require } \\
\text { high dose of autonomy". }\end{array}$ \\
\hline
\end{tabular}


The analysis of the above and many other definitions of knowledge workers indicates different approaches of their authors to the understanding of this concept. These approaches are a derivative of the disciplines represented by the authors and trends in knowledge management described in the literature.

Based on the analysis of the source literature, Gaižauskienè and Tunčikiene describe three approaches to explaining the nature of knowledge workers [23]. According to the data driven approach, knowledge workers are employees professionally related to particular organizations, sectors, or institutions [69,70]. Representatives of job content approach perceive knowledge workers as individuals who do a certain type of job [71-74], while supporters of the conceptual approach explain the term from the point of view of employees' importance for an organization and their style of working with knowledge $[57,58]$.

When defining knowledge workers representatives of the process-oriented approach to knowledge management pay special attention to their participation in the implementation of knowledge management processes (knowledge development, sharing, using, etc.). In turn, representatives of the resource-oriented approach, in which knowledge is treated as the most important resource of organizations operating in the knowledgebased economy, define a knowledge worker through the prism of having this strategic resource $[57,58,64,66]$.

Different approaches to defining knowledge workers are also presented by representatives of two main trends in knowledge management namely: personal (soft, human oriented) and technical (IT, hard, technology oriented) [75-78]. These trends differ mainly in the way information and knowledge are perceived, which in turn determines the expectations with regard to workers working on knowledge in terms of their potential and undertaken actions. Representatives of the technology-oriented trend in KM (often equated with information management) treat information and knowledge as objects that can be identified and processed by information systems. The knowledge worker is primarily expected to be able to know and operate these systems. On the other hand, representatives of the human-oriented trend, related to human resource management, treat knowledge as processes, a set of skills, know-how, etc., which are constantly changing. They assign a special role to people who work with knowledge and on the basis of knowledge and focus on identifying and implementing methods and tools in the area of HRM that will positively affect the implementation of KM processes by knowledge workers.

In our original definition, which combines various approaches to understanding the essence of the knowledge worker, we describe such an employee as a person whose passion, work and professional career are associated with active participation in the knowledge management processes. Knowledge workers are characterized not only by the fact that they have knowledge, experience, skills, etc., important for the organization in which they work, but also the willingness and skills to develop these resources, share them and use them in activities. However, this potential will not be fully realized if the organization does not offer knowledge workers the opportunity to actively participate in the knowledge management processes [79]. Knowledge workers characterized by non-linear and creative thinking, who possess intrinsic creativity and perform creative work, can be considered creative knowledge workers.

Knowledge workers perform knowledge work which is multidimensional in nature and within each dimension there is wide variation in the essence of knowledge, level of work routines and standards, and the role of the persons themselves in work [80]. This view is also shared by D. Morello and F. Caldwell who distinguish different types of knowledge work, such as: task-based knowledge work, revolving around explicit operational processes, pre-engineered routines, well-defined responses and administrative activities, skill-based knowledge work which encompasses well-defined, well-prescribed, demonstrable, conducive to hands-on training domains of expertise, as well as innovationfocused knowledge work, which is characterized by tacit knowledge, high creativity, intense collaboration, communities of practice, high improvisation and extensive role versatility [63]. 
Each of the above-mentioned types of knowledge work consists of a number of activities such as, inter alia: applying, presenting, sharing, analyzing, organizing, evaluating, retrieving, storing, and securing information and knowledge in order to make decisions and take actions. These activities are supported by the use of various IC tools and applications which enable realization of knowledge management processes [81].

In the knowledge-based economy there is limited scope to make a clear distinction between knowledge workers and other employees [25]. Based on the analysis of various definitions and descriptions of knowledge workers, it may be concluded that what distinguishes knowledge workers from other employees is: their knowledge, education, experience, skills, their personal traits, attitudes, their core values, actions taken in the process of work performance or their expectations. In this article, we want to examine this issue in the context of mutual requirements of the knowledge worker and the organization they work for.

Knowledge workers have high expectations of themselves, other people, and the organization in which they work; however, much is also expected of knowledge workers. The expectations of the knowledge workers towards organizations may be broadly categorized into those relating to appropriate: working conditions (financial, organizational, technical, etc.), organizational culture (based on trust, cooperation, open communication, continuous learning), and management of people (involving employees in management, recognition of achievements, creation of professional development opportunities, feedback, professional challenges, etc.). At the same time, knowledge workers are expected, above all, to take actions on knowledge and based on knowledge, to have potential, and to present expected attitudes and behaviors that enable and facilitate the above actions. The expectations listed are interrelated and the categories presented are arbitrary.

The place of the creative knowledge worker in the creative organization is shown in Figure 2.

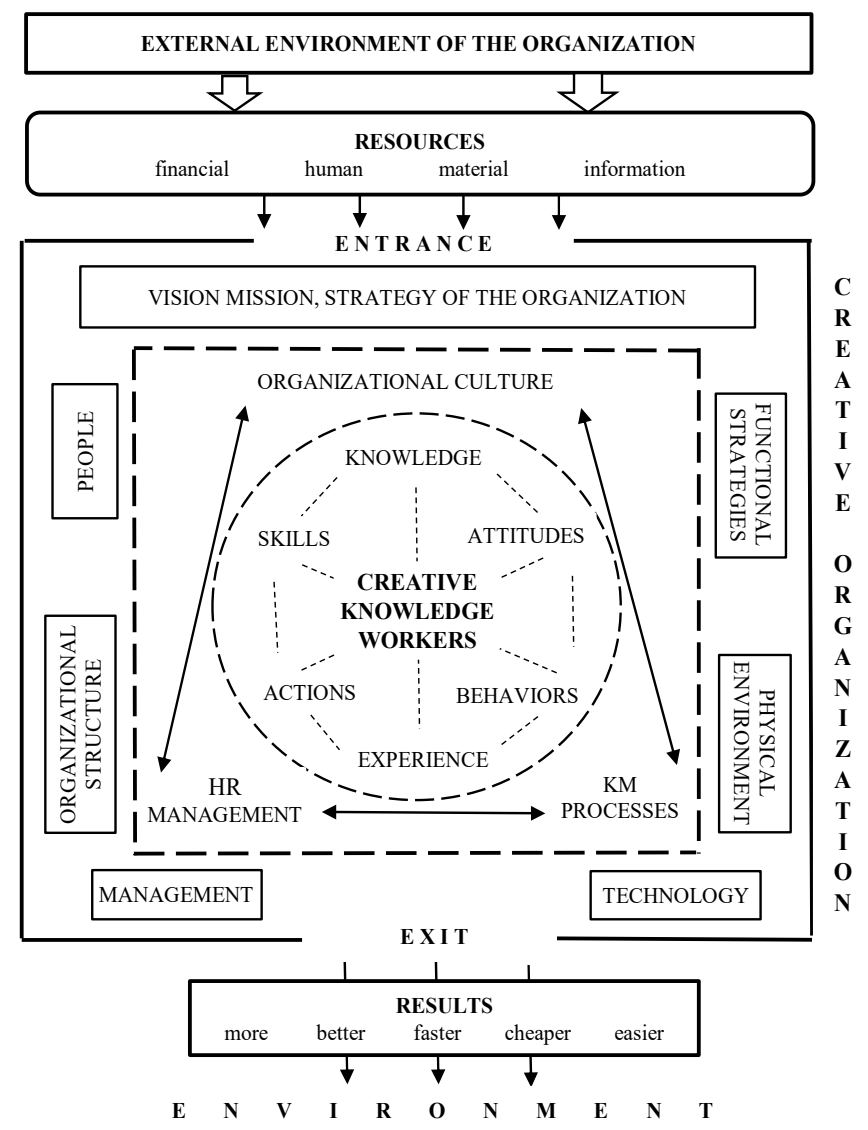

Figure 2. Knowledge worker in the creative organization. Source: created by the authors. 
Creative knowledge worker is at the center of the organization as the owner of potential (including, above all, knowledge), the development and use of which are crucial for the creative organization to achieve a high level of competitiveness on the creative sector market. To make this possible, the shape of the KM processes, the applied methods and tools of HRM, and the organizational culture must be conducive to the development and use of the potential of creative knowledge workers to achieve organizational goals of knowledge management. All elements of the internal organizational environment (people, organizational structures, functional strategies, etc.) relate to each other, shaping the broadly understood working conditions, which translates into the effectiveness of creative knowledge workers. On the other hand, through their decisions, actions, and effects of their work, they may, to a greater or lesser extent, shape this environment. Creative organizations take widely understood resources from the external environment, providing it in turn with the effects of their activities in the form of new (or improved) goods and services.

Taking actions on knowledge and on the basis of knowledge means active participation of knowledge workers in the implementation of knowledge management processes, such as: locating important knowledge sources, acquiring knowledge from various sources, sharing knowledge with other employees, developing knowledge by using various learning methods, preserving knowledge important for the organization, which leads to building organizational memory, and finally using knowledge creatively in the process of decisionmaking and taking actions, which is reflected in new or improved products, services, processes, procedures, methods, etc. [82,83].

The appropriate potential of knowledge workers is an indispensable condition for their active participation in knowledge management processes. Human potential includes a set of positive and negative, used or unused, explicit or tacit traits, and competences of an individual [84]. In the case of knowledge workers, a special attention should be paid to such elements of potential as: knowledge, experience, and skills.

Having knowledge that meets the needs of the organization is a necessary yet insufficient condition for an employee to be considered a knowledge worker. Knowledge is a heterogeneous resource and the literature describes many knowledge types [48,69,85-89]. Knowledge workers are required to have both general and specialist knowledge, with particular importance being attached to tacit knowledge which is located in the human mind and is more personal and less accessible than explicit knowledge. The potential of a knowledge worker is determined to a great extent by their know-how and know-why, as well as by the knowledge that distinguishes them from others, including advanced knowledge enabling them to compete effectively on the market and innovative knowledge that secures their position as experts in the industry.

Experience, sometimes referred to as practical knowledge, is derived from direct observation (of phenomena, processes, people, etc.), participation in events or in a particular professional and non-professional activities (e.g., internships, professional training, previously performed work) that contributed to improvement of qualifications of the person in a given profession.

Skills mean an ability to perform an activity (e.g., job) well. A set of skills important in the knowledge-based economy includes both hard skills, resulting from experience and knowledge acquisition (e.g., ability to use modern ICT tools), and soft skills resulting from personality traits, the possession of which can only be confirmed in practice, through decisions and actions taken by the employee. In the case of knowledge workers particular importance should be attached to skills enabling them to actively participate in knowledge management processes. These skills include, above all, the ability of: working in a team, analytical thinking, flexible thinking and acting, taking the initiative, communicating, networking, learning, adaptation, problem solving, working under stress, self-discipline, independent action, cooperation, active listening, work organization, persuasion, perseverance, mentoring, openness to change, managing own knowledge, and creativity. 
While all the skills mentioned above are crucial for the implementation of knowledge management processes in organizations, in the case of creative knowledge workers, special emphasis should be placed on their creativity in every area and aspect of their work. Creativity should therefore concern not only the results of their work (including new or improved products, services, procedures, etc.), but also the working methods used, the tools employed, etc., as well as the development of other skills mentioned above. Examples include creative approaches to problem solving, organizing one's work or networking.

The elements of knowledge workers potential listed above are strongly interrelated. The greater the knowledge, skills or experience, the more opportunities for a unique combination of these elements in the process of creative work [90].

Knowledge workers are also expected to present desired attitudes, especially positive and pro-active attitudes, which elicit specific behaviors of employees. Positive attitude means focusing on the positive aspects of what is happening around an individual. A knowledge worker is expected to have a positive attitude towards oneself, the organization, co-workers, performed work, responsibility they bear, etc. Pro-active attitude means taking responsibility for own actions and decisions, going beyond the call of duty, finding and seizing opportunities, continued seeking (of inspirations, ideas, new solutions, possibilities etc.), and going beyond daily routines. A pro-active approach of knowledge workers is positively correlated with their creativity and innovativeness [90].

It should also be emphasized that organization's requirements should be reflected in decisions and actions taken by knowledge workers, and vice versa-employees' expectations should influence decisions and actions taken by management of the organizations in which they work. If the organization requires the knowledge worker to undertake certain knowledge management actions, the knowledge worker should require the organization to provide resources and capabilities to undertake these actions and to recognize the results of work performed. Meeting many of the expectations of knowledge workers is possible through their proper management.

The specific nature of knowledge workers management is due to many different factors, however in the context of the issue discussed in this article, special attention should be paid to:

- $\quad$ the specific nature of knowledge as a knowledge workers' strategic resource;

- limited ability to observe and control the work performed by creative knowledge workers;

- $\quad$ the consequences for the organization of not meeting knowledge workers' expectations.

The degree to which an employee uses explicit knowledge can be controlled to certain extent, however determining to what extent and how their tacit knowledge is used (which is the basis of creative activities and the determinant of the competitiveness of individuals and organizations) is not possible, as sometimes even the employee themselves is not fully aware of tacit knowledge possessed. This means that the superior does not have full information about the knowledge possessed by the subordinate, so they cannot assess the extent to which it is used at work. The superior is also not able to accurately assess whether the employee's performance is the result of the full use of their knowledge or whether the employee could have achieved more.

Moreover, the work of the creative knowledge worker is also not fully observable, as it is mostly based on thought processes and takes place in the human mind. Just as the extent to which an employee applies knowledge cannot be fully controlled, the effects and manner of its application cannot always be predicted. Therefore, evaluating a knowledge worker is not an easy task and poses a challenge for managers.

The consequences of not meeting the expectations of knowledge workers can be very severe for an organization operating in the knowledge based economy. A dissatisfied knowledge worker is less committed to their work, focuses on routine activities, or looks for another job and this exposes the organization to the possibility of losing their tacit knowledge which perhaps no one else in the organization has. 
It should also be borne in mind that in a knowledge-based economy, due to the requirements imposed on knowledge workers concerning the actions they undertake, the roles they perform and the responsibility they bear, the distinction between superior and subordinate is gradually blurred. Therefore, managing knowledge workers poses significant challenges to managers, including in respect of their knowledge, experience and skills. Since a manager is also a knowledge worker, apart from the aforementioned requirements imposed on all knowledge workers, superiors are additionally required to possess such skills as e.g.,: delegating tasks (especially those that go beyond daily work routine), team management, motivating (to constant development, sharing knowledge, crossing barriers, etc.), decision-making and leadership, inspiring trust, and courage in taking risks.

The scope of manager's competences and their skillful use has a pro-active influence and inspires creativity not only in the organization as a whole, integrating the actions taken, but also effectively influences the attitudes and actions of employees. Hence, there is a need for a creative organization to manage employees not through a carrot and stick method, but with dignity.

\section{Materials and Methods}

Research on creative organizations was originally initiated by a desk research on the subject of creative sectors. Initially, these studies were conducted by A. Sokót, and then both authors undertook qualitative research in the field of creative organizations, especially in the area of determinants of the knowledge and creativity development in such organizations. The subject matter discussed in this article required a review of the source literature. Articles were identified on knowledge acquisition opportunities, potential sources of knowledge and creativity in terms of creative organization growth. This part of the desk research was dedicated to establishing the theoretical framework and acquiring broader understanding of the relationship between the components selected for the study. The verification procedure adopted in this article involved the examination of certain interrelations between observable phenomena or facts, without any intervention of the researcher. The research was diagnostic and exploratory in nature. The aim of the research was to acquire knowledge about the phenomena in question and to analyze them in order to test the theory, i.e., to confirm or refute it. Moreover, the analysis conducted allowed the authors to organize knowledge and definitions related to the discussed issue.

The main research problem, which is also the subject of the study, is to explore the relationship between creative activities and characteristics of creative knowledge workers as well as knowledge acquisition initiatives. Furthermore, the discussion and final conclusions focus on the impact of the above relationships on the creative organization growth. As the aim of the authors was to carry out an in-depth analysis of the research problem identified, due to a wide research area, hypotheses relating to the following selected issues have been formulated:

Hypothesis 1 (H1). There is a relationship between selected creative activities of employees and selected characteristics of creative knowledge workers.

Hypothesis $\mathbf{2}$ (H2). There is a relationship between creative activities and knowledge initiatives undertaken in creative organizations.

The definition of a creative knowledge worker is presented in Section 3 of this article. Creative activities are those activities undertaken by an employee that are new, previously unknown to him, thanks to which he enriches himself (through the development of knowledge, increase in authority, etc.) and the environment (through new products, services, processes, etc.). In turn, knowledge initiatives are defined as all activities undertaken by an individual aimed at achieving the goal (s) of knowledge management in an organization.

To verify the hypothesis, self-report research with the use of an original questionnaire was used in the article. This method allows to assess the behavior and opinions of the 
respondents taking into account the diagnostic areas selected by the researcher, therefore, it was found to be one of the best methods to verify the research assumptions of this article. In the questionnaire, special attention was paid to questions regarding the performance of creative and reproductive activities in organizations by the respondents. The design of the questions did not allow respondents to guess whether the activities they perform at work are classified as creative or not. Such a solution was applied intentionally in order to obtain the most reliable information on which employees work creatively and which do not. It is important to realize that the more creative activities in an organization, the more creative solutions are produced and the more likely a creative organization is to grow. The source literature often describes creative workers by their personality traits defined by well-known and widely used psychological methods, which allow determining whether an individual has such a potential or not. The authors have also carried out numerous analyses in this respect in their studies. It is assumed that all people are creative, and differ only in their level of creativity. However, working as an employee with creative potential does not always mean carrying out creative activities. For this reason, this study takes a focused look and sets out to investigate whether and to what extent employees in creative organizations perform creative activities on a daily basis. The above procedure was adopted to analyze the work of the respondents. Further questions concerned the characteristics including creative attitudes of knowledge workers and knowledge acquisition initiatives as sources of knowledge development in creative organizations.

At this point, it should be added that the survey questionnaire, apart from the questions analyzed in this article, also included other research questions that identify various areas related to the development of creative organizations and resources such as creativity or knowledge. The respondents were asked, inter alia, about the number of creative work performed in the last few years, barriers to the development of knowledge and creativity in the organization, types of information and communication technologies used in the organizations where research participants work, preferred ways of learning and applied methods of solving problems related to knowledge and creativity management. When constructing the questionnaire, care was taken to make it transparent and understandable to the respondent. This article begins a series of thematic studies based on the research results obtained by the authors, which will be successively presented in scientific journals. The questionnaire used in the study was based on the authors' many years of experience in exploring the subject of knowledge and creativity management, which was reflected in many scientific publications [1,18,91-94].

After defining the sampling frame, i.e., a set of items in a statistical population used to verify the formulated hypotheses, a research sample was drawn. The sample was drawn using a stratified non-proportional random sampling method. The sample group, as indicated above, consisted of individuals employed in creative organizations who perform creative activities. Continuous knowledge acquisition was another criterion for classification in the sample group. Hence, the sample was drawn from adults who were not only employees but also management students at the last two years of their studies (hereinafter also referred to as subjects, sample group, respondents). This decision was based on the fact that studies allow continuous acquisition of new knowledge and development of creativity. Due to their availability, the respondents were a group of individuals from the Zachodniopomorskie Province studying at the same university. This fact did not affect their responses and facilitated the control and evaluation of the study population.

The respondents were informed about the purpose of the study and the method of completing the questionnaire. Due to the limitations of the COVID-19 pandemic, the respondents were asked to complete a questionnaire in the electronic form (online) within 1 clock hour. In addition to the metric questions, the survey questionnaire contained 13 closed and semi-open questions and was pre-tested on a control group of 30 people. In order to assess whether the prepared questionnaire would be fully understandable to the sample group, pilot studies were carried out on one of the selected faculties. After assessing 
the results, the proper study was conducted. The study was conducted between 20 October 2020 and 15 May 2021.

In order to ensure an adequate number of questionnaires, it was decided to survey 350 respondents. A total of 280 properly completed full questionnaires were returned. This quantity met the minimum sample size criterion and allowed a lower error rate to be achieved. 157 of the respondents were women. The respondents aged up to 25 accounted for $77.5 \%$ of the surveyed group, and those aged 26 to 35-nearly $14 \%$. The majority of respondents had work experience ranging from 1 to 5 years (209 people), 30 people indicated 6 to 10 years of professional activity, and the remaining group of participants had worked for more than 10 years. The respondents worked in organizations of different size of employment. $27.5 \%$ of the respondents worked in organizations employing less than 10 employees, three out of ten persons surveyed - in those employing from 11 to 50 people, $13.9 \%$ of the survey participants were professionally connected with organizations employing from 50 to 250 employees, and the remaining participants were employed in business entities employing more than 250 people (18.2\%) or did not answer this question.

The collected data were coded in a research matrix in an Excel file and further analyzed using SPSS program. The results obtained, discussed in the context of the hypotheses formulated, are presented in the following section.

\section{Results}

The theoretical considerations were verified by empirical analysis carried out according to research sequences based on findings emerging from the questionnaire responses. The first stage (stage I) of the analysis involved the processing of the data obtained. This was followed by a verification of the hypotheses (stage II) and a comparison with the theoretical part of the material obtained. Stage III presents the final conclusions and suggestions for managers of creative organizations on how to stimulate the development of creative knowledge workers so that they undertake more creative activities and extend their knowledge. To test the hypotheses made, statistical analyses were performed using the IBM SPSS package. Spearman's correlation coefficient was calculated to measure the association between ordinal variables. Next, the strength of relationship between nominal and ordinal variables was measured using chi-square tests. The limit of statistical significance was $p<0.05$.

The first research aspect was to assess the relationship of the characteristics prevalent among creative knowledge workers and the characteristics of activities defined as creative. For a better understanding of the results of the conducted analysis, it is worth noting that the characteristics of a creative knowledge worker as well as creative and reproductive activities were developed on the basis of the scientific literature in the field of psychology [95-103]. The individual columns of Table 3 indicate the following characteristics of the employee: (1) precision, reliability, efficiency, methodicalness, discipline as well as conformism, (2) focusing on problem solving rather than problem identification, (3) looking for proven solutions to problems, (4) dealing with problems through effective actions with maximum continuity, (5) being perceived as a conformist, dependent person, (6) relying on known means of achieving goals, (7) being rarely bored, performing time-consuming tasks with great precision, (8) taking over leadership within existing structures, (9) rarely questioning established rules and only with strong backing, (10) having a tendency to lack self-confidence, reacting to criticism with even greater conformism, falling under social influence and power, (11) being relevant to the operation of an organization, yet sometimes revealing tendency to hide (immerse) in one's work, (12) attention to stability, order and effective cooperation when working with innovators, (13) sensitivity to other people, fostering group cohesion and cooperation, (14) laying a secure foundation for risky behavior of innovators. In turn, the individual lines of Table 3 represent the activities described as follows: (1) known, perceived many times activity, (2) known, repeated or even algorithmized activity, (3) known, used many times activity, (4) usually a simple activity, reduced to a minimum, of an imitative nature, (5) activity condensed in time, 
(6) usually fixed, often even automated and habitual activity, (7) immediate feedback activity, positive reinforcement, (8) unknown, new, unique, interesting activities (9) new, non-routine, frequently changing, challenging activities performed at work, (10) the use of new tools, new, interesting, frequently changing methods in the process of performing activities, (11) surprising and creative decisions enabling innovation, (12) non-routine, unspecified time of performing activities, (13) variable activities related to new tasks.

Table 3. Correlation between the tested values.

\begin{tabular}{|c|c|c|c|c|c|c|c|c|c|c|c|c|c|c|}
\hline & 1 & 2 & 3 & 4 & 5 & 6 & 7 & 8 & 9 & 10 & 11 & 12 & 13 & 14 \\
\hline 1 & 0.001 & 0.717 & 0.466 & 0.420 & 0.220 & 0.470 & 0.437 & 0.033 & 0.000 & 0.055 & 0.046 & 0.421 & 0.010 & 0.054 \\
\hline 2 & 0.000 & 0.684 & 0.151 & 0.021 & 0.711 & 0.436 & 0.501 & 0.144 & 0.000 & 0.016 & 0.760 & 0.197 & 0.420 & 0.476 \\
\hline 3 & 0.211 & 0.993 & 0.075 & 0.326 & 0.653 & 0.004 & 0.737 & 0.008 & 0.091 & 0.513 & 0.392 & 0.668 & 0.836 & 0.030 \\
\hline 4 & 0.004 & 0.341 & 0.823 & 0.740 & 0.258 & 0.566 & 0.989 & 0.011 & 0.006 & 0.209 & 0.827 & 0.391 & 0.965 & 0.062 \\
\hline 5 & 0.001 & 0.216 & 0.783 & 0.645 & 0.606 & 0.534 & 0.666 & 0.370 & 0.036 & 0.505 & 0.085 & 0.379 & 0.414 & 0.477 \\
\hline 6 & 0.000 & 0.818 & 0.263 & 0.002 & 0.463 & 0.816 & 0.008 & 0.211 & 0.004 & 0.347 & 0.339 & 0.228 & 0.043 & 0.022 \\
\hline 7 & 0.000 & 0.153 & 0.956 & 0.155 & 0.377 & 0.539 & 0.263 & 0.204 & 0.604 & 0.167 & 0.924 & 0.004 & 0.402 & 0.056 \\
\hline 8 & 0.294 & 0.013 & 0.218 & 0.441 & 0.328 & 0.003 & 0.713 & 0.480 & 0.061 & 0.009 & 0.138 & 0.600 & 0.887 & 0.940 \\
\hline 9 & 0.878 & 0.018 & 0.490 & 0.526 & 0.241 & 0.017 & 0.911 & 0.139 & 0.853 & 0.469 & 0.850 & 0.739 & 0.298 & 0.534 \\
\hline 10 & 0.295 & 0.005 & 0.191 & 0.076 & 0.001 & 0.226 & 0.315 & 0.799 & 0.191 & 0.082 & 0.356 & 0.074 & 0.326 & 0.705 \\
\hline 11 & 0.011 & 0.013 & 0.752 & 0.036 & 0.009 & 0.001 & 0.411 & 0.745 & 0.024 & 0.000 & 0.173 & 0.056 & 0.558 & 0.836 \\
\hline 12 & 0.098 & 0.004 & 0.017 & 0.078 & 0.008 & 0.049 & 0.626 & 0.270 & 0.312 & 0.000 & 0.005 & 0.750 & 0.546 & 0.023 \\
\hline 13 & 0.311 & 0.020 & 0.307 & 0.270 & 0.003 & 0.011 & 0.056 & 0.340 & 0.865 & 0.011 & 0.018 & 0.892 & 0.047 & 0.641 \\
\hline
\end{tabular}

Source: Own research.

The analysis of the results demonstrated statistically significant correlations in the sample group between (Table 3):

1. such personality traits as precision, reliability, efficiency, methodicalness, discipline as well as conformism and taking surprising and creative decisions enabling innovation;

2. focusing on problem solving rather than problem identification and unknown, new, unique, interesting results of activities performed at work; new, non-routine, frequently changing, challenging activities performed at work; the use of new tools, new, interesting, frequently changing methods in the process of performing activities; taking surprising and creative decisions enabling innovation; non-routine, unspecified time of performing activities; performing variable activities related to new tasks;

3. looking for proven solutions to problems and a non-routine, unspecified time of performing activities;

4. dealing with problems through effective actions with maximum continuity and taking surprising and creative decisions enabling innovation;

5. being perceived as a conformist, dependent person and performing variable activities related to new tasks;

6. relying on known means of achieving goals and a non-routine, unspecified time of performing activities;

7. being rarely bored, performing time-consuming tasks with great precision and the use of new tools, new methods, interesting, frequently changing methods in the process of performing activities; taking surprising and creative decisions enabling innovation; non-routine, unspecified time of performing activities; performing variable activities related to new tasks;

8. taking over leadership within existing structures and unknown, new, unique, interesting results of activities performed at work; new, non-routine, frequently changing, challenging activities at work; taking surprising and creative decisions enabling innovation; performing variable activities related to new tasks;

9. rarely questioning established rules and only with strong backing no correlation with the characteristics of creative knowledge workers; 
10. having a tendency to lack self-confidence, reacting to criticism with even greater conformism, falling under social influence and power no correlation with the characteristics of creative knowledge workers;

11. being relevant to the operation of an organization, yet sometimes revealing tendency to hide (immerse) in one's work and taking surprising and creative decisions enabling innovation;

12. attention to stability, order and effective cooperation when working with innovators and unknown, new, unique, interesting results of activities performed at work; new, non-routine, frequently changing, challenging activities performed at work; taking surprising and creative decisions enabling innovation; non-routine, unspecified time of performing activities; performing variable activities related to new tasks;

13. sensitivity to other people, fostering group cohesion and cooperation and non-routine, unspecified time of performing activities; performing variable activities related to new tasks;

14. laying a secure foundation for risky behavior of innovators and usually immediate feedback, positive reinforcement.

Due to the importance of knowledge and the necessity of its continuous acquisition in the development of creative attitudes and performance of creative activities in creative organizations, at the next stage of the study, the relations between the performance of creative activities by employees in their everyday work and knowledge initiatives determining the execution of knowledge management processes in organizations were examined. The first step in evaluating the results of the study was to analyze the relationships between nominal and ordinal variables using the chi-square test. The results revealed significant relationships between the following variables:

1. activities usually involving immediate feedback, positive reinforcement and the following knowledge initiatives: (1) developing knowledge maps; (2) creating contact books; (3) internal training/workshops (4) external training/workshops; (5) formation of knowledge teams to develop KM methods and tools; (6) anecdotes and internal case studies; (7) using procedures to document information; (8) cooperation with research centers, universities; (9) conducting own market research; (10) outsourcing; (11) conducting employee evaluations;

2. unknown, new, unique, interesting activities and the following knowledge initiatives: (1) development of knowledge maps; (2) establishment and development of so-called communities of practice; (3) benchmarking; (4) obtaining information from providers; (5) development of own computer-based knowledge management systems; (6) establishment of career paths; (7) providing employees with trade and professional press and publications; (8) cooperation with other companies; (9) cooperation with research centers, universities;

3. new, non-routine, frequently changing, challenging activities with the following knowledge initiatives: (1) external training/workshops; (2) formation of knowledge teams to develop KM methods and tools; (3) development of own computer-based KM systems; (4) organizing chat rooms or other meeting places for employees; (5) organizing brainstorming sessions; (6) team analysis of successes and failures following project completion (After Action Review, AAR);

4. activities requiring new tools, new methods, interesting, frequently changing methods with the following knowledge initiatives: (1) external trainings/workshops; (2) benchmarking; (3) formation of knowledge teams to develop KM methods and tools; (4) conducting research on customer needs; (5) providing employees with trade and professional press and publications; (6) cooperation with research centers, universities; (7) relocating employees to other companies (e.g., for internship); (8) building a network of experts from within and outside an organization; (9) participation in conferences, seminars;

5. activities related to surprising and creative decisions enabling innovation with the following knowledge initiatives: (1) formation of knowledge teams to develop KM 
methods and tools; (2) conducting research on customer needs; (3) obtaining information from providers; (4) conducting own market research; (5) participating in conferences, seminars; (6) outsourcing;

6. non-routine, unspecified activities with the following knowledge initiatives: team building trips or meetings;

7. variable activities related to new tasks with the following knowledge initiatives: (1) establishment and development of so-called communities of practice; (2) external training/workshops; (3) conducting research on customer needs.

\section{Discussion}

Due to turbulent environment and a fast rate of change, organizations urgently seek more effective methods of operation. Creative organizations rely on the resources of creativity and knowledge to achieve success. Their aim is to ensure the development of employees providing these resources, to gain competitive advantage. Hence, such organizations most value managerial employees and distinguished professionals with unique knowledge and creative potential. Their value comes from exceptional skills that comprise the organization's core competencies. These employees are so valuable to the organization because, among other things, they are the ones who mainly promote change and come up with new ideas, products, or services. The formation of a creative entity and the emergence of a new type of employees-creative knowledge workersadditionally affect the nature of the work carried out by managers. Hence, the work of the management staff, including creative managers, is nowadays focused on building human capital as a strategic asset of an organization that allows it to compete effectively in the highly competitive market. In the light of the above, the study first examined selected characteristics of creative knowledge workers who perform creative activities in their daily work. These creative activities have been described as: unknown, new, unique, interesting results of activities performed at work; new, non-routine, frequently changing, challenging activities; the use of new tools, new, interesting, frequently changing methods in the process of performing work; taking surprising and creative decisions enabling innovation; nonroutine, unspecified time of performing activities; including performing variable activities related to new tasks. This was followed by the verification of the characteristics of creative knowledge workers in the context of the above activities.

The analysis of selected skills of creative knowledge workers indicates that they should undertake new tasks at work and should not be apprehensive about their level of difficulty - even if they have not performed the task before and are afraid of making mistakes. Making mistakes is inherent in a creative search for solutions. Mistakes made may ultimately lead to the right solution. Moreover, a creative knowledge worker should be committed to work-creativity requires intellectual effort, knowledge, and time.

The data obtained from the study indicated that creative activities generally characterized by immediate feedback and positive reinforcement were the only ones that demonstrated association with the predisposition of a creative knowledge worker to lay a secure foundation for risky behavior of innovators. Research presented in the literature shows that creative activities require making prompt decisions and decisions teetering on the edge of risk [104]. According to Sternberg et al. [105], there is a certain level of uncertainty associated with creative projects and activities that should not be avoided but managed by an organization. Not all creative projects will succeed; however, this is not a reason to avoid creative experimentation, as possible failures will be compensated by other successful projects.

It is worth noting that respondents who performed creative activities aimed at using new tools, new, interesting, and frequently changing methods in the process of performing activities are rarely bored and perform time-consuming tasks with great precision. The source literature suggests that this may be related to one of the characteristics of a creative knowledge worker, i.e., openness to experience. This factor is considered to be the most indicative of creativity e.g., [106]. It has been proven that creative individuals 
demonstrating great openness to innovation produce significantly more new ideas [107]. Openness includes such qualities as intellectual curiosity, originality, non-conformity, active imagination, aesthetic sensitivity, and a preference for variety. Individuals who demonstrate great openness to experience are considered to be broad-minded, progressive and non-traditional [106]. Furthermore, openness to innovation stems from two other creativity-correlated personality traits which include: divergent thinking and cognitive style. Divergent thinking characterizes an individual who is adept at producing original ideas $[108,109]$. Cognitive style is an individual style of thinking and retaining information allowing a person to solve problems and make decisions which are considered part of creative processes [110]. In addition, creative knowledge workers should adhere to their beliefs and views and believe that their ideas will gain approval from others. They should be firm but, at the same time, open to opinions of others. Contradictions and conflicts regarding a given problem have often led to the desired solutions. Creative knowledge workers should properly select the necessary means which will be most effective in communication with those collaborating on a task.

Unfortunately, the research also reveals a negative aspect, as individuals who perform creative activities (aimed at using new tools, new, interesting methods in the process of performing activities) tend to focus on problem solving rather than problem identification. This stands in opposition to the other characteristics of a creative knowledge worker indicated above, who should rather be innovation-oriented.

The analysis of the next research area revealed an interesting research aspect: individuals performing activities with unknown, new, unique and interesting results as well as new, non-routine, frequently changing, and challenging activities at work tend to take over the leadership within the existing structures and be attentive to stability, order, and effective cooperation when working with innovators. This broad category includes all activities carried out by such people that influence organizational creativity. It is also about their direct responsibility and their behavior. Filipczak [111] and Bresnahan [112] emphasize the importance of the role played by managing in generating value for the organization resulting from creative work. Analyzing the literature on the subject, it can be indicated that for the climate of creativity at the level of management support, it is important that [1,112-115]: managers set a role model for their employees; employees were provided with autonomy in action and decision making; employees were provided with appropriate (not only mental) support and encouraged to undertake creative activities; the leadership style motivated employees to work.

Another aspect of the respondents' creative activities was taking surprising and creative decisions enabling innovation. It should be emphasized that creativity requires quick and risky decisions [104]. It is believed that there is a certain level of uncertainty about creative projects and activities that an organization should not avoid but manage [105]. Not all creative projects will be successful, however, this is not a reason to avoid creative experiments, as possible failures will be compensated by other successful projects. The data showed correlations with such characteristics as: being rarely bored, performing timeconsuming tasks with great precision (the same correlation was observed with activities aimed at using new tools, new, interesting methods in the process of performing activities), taking over leadership within existing structures, being relevant to the operation of an organization, yet sometimes revealing tendency to hide (immerse) in one's work, paying attention to stability, order and effective cooperation when working with innovators. Surprisingly, such individuals also displayed traits such as precision, reliability, efficiency, methodicalness, discipline, and conformism, in addition to focusing on solving problems rather than problem identification, dealing with problems through effective action with maximum continuity.

This was followed by an analysis of creative activities of a non-routine nature and unspecified time. It is true that creativity requires not only a certain amount of resources, but also time [115-118]. The first ideas require discussion and verification. The more time is spent on ideas and their generation and implementation, the higher the level of 
creativity can be achieved. According to the results of the study, such individuals were also characterized by sensitivity to other people, fostering group cohesion and cooperation, attention to stability, order and effective cooperation when working with innovators. The source literature suggests that a creative knowledge worker should be oriented towards individual work but also towards group work. Working together can often produce more creative solutions than working alone. However, it is worth stressing that it is not a rule and the above statement is debatable, as everything comes down to the task to be performed, the sector, as well as the potential that is at the disposal of an organization. Nevertheless, certain tasks require individual solutions. According to the results of the research, a creative knowledge worker tends to focus on solving problems rather than identifying them, look for proven solutions to problems, and rely on known means of achieving goals.

Another creative activity connected with the performance of variable activities related to new tasks showed correlation with being rarely bored, performing time-consuming tasks with great precision, attention to stability, order, and effective cooperation when working with innovators, sensitivity to other people, fostering group cohesion and cooperation, but also with being perceived as a conformist, dependent person. It is worth noting that this type of workers consider unfamiliar situations as interesting, exciting, harmless and inspiring creative responses [119]. Such a worker should also be characterized by moderate conscientiousness. Individuals with a high degree of conscientiousness are described as careful, orderly, persistent, reliable, responsible and composed. However, creative workers should display moderate conscientiousness. Overly conscientious individuals can often take actions that inhibit creativity. Research shows that there is a strong domain relationship between conscientiousness and creativity, which means that depending on the type of creativity, conscientiousness increases or decreases its level. It has been demonstrated, for example, that artistic creativity is not correlated with conscientiousness [120-122] after [107]. Creativity is associated with perseverance to see actions through to completion. It is determined by appropriate motivation-achievement motivation and intrinsic motivation. When combined, these character traits are extremely important for creativity, as they allow a reasonable and effective evaluation of the actions taken to develop new ideas, processes or products [123] However, it is worth noting that extrinsic motivation can reduce creativity, while intrinsic motivation can increase it [107].

Moreover, creative workers should use the power of intuition and their intelligence. Hunches, although not very tangible, highly individual and attributed to a specific person, may be the proper point of reference for finding the right solutions. It is also recommended that they have a high degree of extroversion which is characterized by the following traits: active, energetic, expressive, sociable, optimistic [123]. Optimism is a strong belief that positive events will prevail in the future. This attitude determines the motivational potential to undertake difficult and unusual tasks. Optimism is also associated with a good mood which contributes to many new ideas. According to certain studies, however, a creative worker's bad mood does not always lead to a reduction in creative potential. Sometimes anger may give rise to new solutions. In such a situation, perseverance in the pursuit of goals is of crucial importance $[106,124]$. It is worth noting that one of the well-known theories by Scheier and Carver [125] attributes a significant role to functional optimism in motivational processes.

Unfortunately, the research once again indicates a negative aspect, as people performing this kind of creative activities (involving variable activities related to new tasks) focus on problem solving rather than problem identification and take over leadership within existing structures.

Finally, it is worth noting that there are also creative activities listed in the study that did not show an association with the listed characteristics of creative knowledge workers. These included the following:

1. rarely questioning established rules and only with considerable backing;

2. having a tendency to lack self-confidence, reacting to criticism with even greater conformism, falling under social influence and power. 
In conclusion, it is considered that creative knowledge workers should adhere to their beliefs and views and believe that their ideas will gain approval from others. They should be firm but, at the same time, open to opinions of others. Contradictions and conflicts regarding a given problem have often led to the desired solutions. Creative knowledge workers should properly select the necessary means which will be most effective in communication with those collaborating on a task.

The relationships between selected creative activities and knowledge initiatives were then examined. Knowledge initiatives involve any actions taken by employees aimed specifically at achieving knowledge management objectives derived from the organization's objectives. Knowledge initiatives affect how knowledge in the organization is created, shared and embedded in the products of human labor. There are attempts to make practical use of knowledge, to accomplish objective of the organization through the unique connection of the man, technology and content on the basis of: [126]. It may be said that knowledge initiatives include actions taken on and based on organizational knowledge, which are interrelated and pertain to different areas of knowledge management (personal, cultural, technological). Certain initiatives are introduced with awareness of their positive impact on the implementation of KM processes in organizations, while others are introduced intuitively, even by those organizations that have not implemented knowledge management concepts. Analysis of knowledge initiatives reveals a certain set of patterns of solutions adopted that may be modified to creatively solve new problems arising in an organization, develop new products, services, improve processes, etc.

The analysis of correlation between creative activities and specific knowledge initiatives undertaken by creative knowledge workers indicated certain associations and led to certain conclusions.

The largest number of knowledge initiatives (eleven) are associated with activities that generally involve immediate feedback, positive reinforcement. Nine knowledge initiatives are associated with activities that are unknown, new, unique, interesting, and with activities that require new tools, new, interesting, frequently changing methods. The awareness of these associations is important in terms of effective knowledge management as well as human resource management and knowledge worker creativity management. This is because it allows the identification of initiatives which, in relation to individual knowledge workers performing specific creative activities, may produce extraordinary results, and then taking action to enable and motivate employees to actively participate in these initiatives.

The initiatives associated with four i.e., the largest number of creative activities described in this article include the formation of knowledge teams to develop knowledge management methods and tools and external training/workshops. Both initiatives are associated with activities that usually involve immediate feedback, positive reinforcement, with activities that are new, non-routine, changing frequently, and challenging, and with activities that require new tools, new, interesting and frequently changing methods. The former initiative has also been linked to taking surprising and creative decisions, while the latter to variable activities related to new tasks.

Related to the three types of creative activities are initiatives such as cooperation with research centers, universities, and conducting research on customer needs. Both initiatives are related to activities that require new tools, new, interesting, and frequently changing methods. Cooperation with research centers, universities is also correlated with activities which usually involve immediate feedback, positive reinforcement, as well as with unknown, new, unique, and interesting activities. Conducting research on customer needs as a knowledge initiative is associated with surprising and creative decisions enabling innovation, as well as with variable activities related to new tasks.

It should be emphasized that the initiatives connected with the highest number of creative activities are the initiatives aimed primarily at the development of knowledge through teamwork, joint action, knowledge sharing and learning. These activities, and knowledge sharing in particular, require mutual trust $[79,127,128]$, which is integral to an organization's culture that fosters knowledge management and creativity. 
Knowledge development, allowed through active participation in knowledge initiatives, is positively correlated with creativity, as it creates more unique opportunities to combine knowledge with experience and skills in the process of producing creative works. It is important to remember that in order for creative ideas of knowledge workers (as is the case with knowledge) to bring about measurable effects, i.e., increased effectiveness of the organization's operations, they must be put into practice $[127,128]$. Furthermore, it is indicated that it is the organization's ability to use knowledge and creativity that determines the strength of knowledge and creativity impact on the results achieved by an organization $[129,130]$. However, expertise, as pointed out by P. Mannucci [131] may become "an inflexible, airless mass" and inhibit creativity. For this reason, creative knowledge workers are advised to undertake activities which go beyond their area of expertise in order to maintain flexibility of cognitive processes. Attending conferences or reading articles are, according to the author quoted above, examples of activities that can effectively counteract the cognitive rigidity of employees and that constitute knowledge initiatives.

Therefore, all knowledge initiatives, including those oriented towards knowledge development, should be given considerable importance not only in respect of knowledge management in an organization, but also management of knowledge workers' creativity.

\section{Conclusions}

Creativity in the context of organizations may be defined as the ability and motivation of in individual to constantly seek and use in practice the results of scientific research, new concepts, inventions and patents. To succeed in the 21st century, an organization must continually improve and transform itself into an entity of the future. It also entails tolerance for diversity and otherness. Lasting success requires not only foresight, but shaping future that is part of forward thinking. Therefore, nowadays, individuals and organizations that learn, produce knowledge and turn it into innovations are in the lead. They offer growth prospects using mechanisms of permanent renewal, a kind of revitalization, and above all-as part of modernization measures to comply with the emerging model of a flexible enterprise - they introduce the concept of management based on knowledge and creativity.

Considering the above, attention should be paid in a creative organization to the development of creative knowledge workers who are the source of knowledge and creativity. The ability of an individual to perform certain work in such an organization and display behaviors that produce expected results is extremely desirable. Therefore, the efficiency of action, including undertaking activities of a creative nature, or the ability to apply knowledge should be measured on the basis of predictors, i.e., the qualities and characteristics of an individual constituting a certain potential which, through appropriate management, motivation methods and organizational support, may be unlocked.

Thus, to sum up the above reflections on creative knowledge workers as well as the research results obtained, it should be noted that a person who performs creative activities is characterized by:

- attention to stability, order, and effective cooperation when working with innovators;

- sensitivity to other people, fostering group cohesion and cooperation;

- laying a secure foundation for risky behavior of innovators;

- being relevant to the operation of an organization, yet sometimes revealing tendency to hide (immerse) in one's work;

- taking over leadership within existing structures;

- being rarely bored, performing time-consuming tasks with great precision;

- relying on known means of achieving goals;

- dealing with problems through effective action with maximum continuity;

However, interestingly enough, such a person may also: be seen as a conformist, dependent person, focus on problem solving rather than problem identification or be characterized by precision, reliability, efficiency, methodicalness, discipline, and conformism.

Furthermore, the article demonstrates a relationship between creative activities and knowledge initiatives. Creative knowledge workers form a heterogeneous group whose 
work and responsibilities cover a wide spectrum of creative activities. Understanding the nature of associations between the discussed activities and particular knowledge initiatives is crucial for identifying the knowledge initiatives which will bring the best effects to a given organization through effective performance of creative workers. Significant correlations (the second hypothesis) were demonstrated in particular for the following initiatives which were of great importance for the achievement of the above-mentioned effect: forming knowledge teams to develop knowledge management methods and tools; external trainings/workshops; cooperation with research centers, universities, as well as conducting research on customer needs. Above all, these initiatives enable the development of knowledge, facilitate knowledge sharing and its creative application in decision-making and taking action, contributing to the success of creative organizations operating in a knowledge-based economy.

The analysis carried out in this article concerns creative organizations and creative knowledge workers. This research is part of both the knowledge and creativity management processes in the organization. The results obtained in this study enrich the literature on this subject, but also allow to indicate the implications for people managing this type of organizations. According to the authors, the above results, and to some extent the guidelines, can be successfully applied to all organizations, because in each of them one can find the dimension of the development of knowledge and creativity. The difference is that some organizations are primarily creative-oriented, while others make little use of creativity. Bearing in mind the above aspects, it is possible to list a number of benefits that result from the conducted research for the organization, which will: generate added value in the organization, contribute to an increase in the competitiveness of the organization, better stimulate the development of the individual, introduce new ideas, products or services to the market more efficiently, improve the functioning within the organization in terms of creative solutions, support the individual creativity of employees, which contributes to increasing the creativity of the team and better determine the actions of the group and its members to think.

Summing up the above considerations it should be emphasized that the scientific goal of the article was achieved by explaining and extending the conceptualization in the field of creative activities performed by the examined creative knowledge workers and the relationships between them and both their characteristics and knowledge initiatives. However, in the context of this study, several limitations need to be acknowledged. One of them concerns the selection of the questions used in the questionnaire, despite the fact that it was prepared with careful care and based on available analyzes, theories, reports as well as the knowledge and experience of the authors. A limitation is also the fact that the study was conducted on a narrow group of studying creative knowledge workers, therefore turning the obtained results into the entire population of creative knowledge workers may be a subject to error. Another limitation concerns the issue of the methods used and other possible research results concerning research aspects not discussed in this article. Therefore, it is suggested to conduct an empirical study to demonstrate the relationship between selected research areas with the use of different complementary diagnostic tools (e.g., focus studies). The last limitation is related to the fact that selected characteristics of creative knowledge workers may be subjective in the readers' opinion.

The described limitations are the starting point for determining further research directions. On the one hand, it is suggested to further develop diagnostic tools allowing for even better, more detailed research in the field presented in this study, and on the other hand, to expand the research group. Being aware of the fact that the obtained research results do not exhaust the issues related to the development of knowledge and creativity in a creative organization, but constitute an introduction to further research and analysis, the authors plan to investigate the impact of other aspects related to knowledge and creativity management (e.g., elements of organizational culture conducive to knowledge and creativity management, such as trust, cooperation, continuous learning) on creative activities undertaken by creative knowledge workers. The analysis of these issues in the 
theoretical and empirical dimensions will allow to indicate other additional areas for the development of creative organizations, such as the absorption of new knowledge in creative activities or improvement of the organization of creative processes.

Author Contributions: Conceptualization, A.S. and I.F.; methodology, A.S. and I.F.; validation, A.S. and I.F.; formal analysis, A.S. and I.F.; investigation, A.S. and I.F.; resources, A.S. and I.F.; data curation, A.S. and I.F.; writing-original draft preparation, A.S. and I.F.; writing-review and editing, A.S. and I.F.; visualization, A.S. and I.F. All authors have read and agreed to the published version of the manuscript.

Funding: This research was funded from the reserve of the Director of Management Institute of the University of Szczecin and from the reserve of the Vice-Rector for Science at the Pomeranian University in Słupsk, Poland.

Conflicts of Interest: The authors declare no conflict of interest.

\section{References}

1. Sokół, A. Zarządzanie Twórczościa w Organizacji. Koncepcja, Metody i Narzędzia; CeDeWu: Warsaw, Poland, 2015.

2. Mathisen, G.E.; Einarsen, S.; Jørstad, K.; Brønnick, K.S. Climate for work group creativity and innovation: Norwegian validation of the team climate inventory (TCI). Scand. J. Psychol. 2004, 45, 383-392. [CrossRef] [PubMed]

3. DiLiello, T.C.; Houghton, J.D. Maximizing organizational leadership capacity for the future. J. Manag. Psychol. 2010, 21, 319-337. [CrossRef]

4. Slåtten, T.; Svensson, G.; Sværi, S. Empowering leadership and the influence of a humorous work climate on service employees' creativity and innovative behaviour in frontline service jobs. Int. J. Qual. Serv. Sci. 2011, 3, 267-284. [CrossRef]

5. Ibrahim, N.H.; Haron, S. Conceptualizing employee's creativity and innovation for effective leadership. In Proceedings of the 2nd Technology, Science, Social Sciences \& Humanities International Conference (TeSSHI), Kedah, Malaysia, 5-6 November 2014. Available online: https://www.researchgate.net/publication/271447492_Conceptualizing_Employee\%27s_Creativity_And_ Innovation_For_Effective_Leadership (accessed on 29 April 2021).

6. Liu, C.-H.S. Examining social capital, organizational learning and knowledge transfer in cultural and creative industries of practice. Tour. Manag. 2018, 64, 258-270. [CrossRef]

7. Luu, T.T. Can diversity climate shape service innovative behavior in Vietnamese and Brazilian tour companies? The role of work passion. Tour. Manag. 2019, 72, 326-339. [CrossRef]

8. Zhou, J.; Shalley, C.E. Handbook of Organizational Creativity; Lawrence Erlbaum: New York, NY, USA, 2008.

9. Anderson, N.; Potočnik, K.; Zhou, J. Innovation and creativity in organizations: A state-of-the-science review, prospective commentary, and guiding framework. J. Manag. 2014, 40, 1297-1333. [CrossRef]

10. Woodman, R.W.; Sawyer, J.E.; Griffin, R.W. Toward a theory of organizational creativity. Acad. Manag. Rev. 1993, 18, 293. [CrossRef]

11. Amabile, T.M. A model of creativity and innovation in organizations. In Research in Organizational Behaviour; Staw, B.M., Cummings, L.L., Eds.; JAI Press: Greenwich, CT, USA, 1988; Volume 10, pp. 123-167.

12. Amabile, T.M. Creativity in Context: Update to the Social Psychology of Creativity; Westview Press: Boulder, CO, USA, 1996.

13. Ford, C.M. A Theory of individual creative action in multiple social Domains. Acad. Manag. Rev. 1996, 21, 1112-1142. [CrossRef]

14. Amabile, T.M. Motivating creativity in organizations: On doing what you love and loving what you do. Calif. Manag. Rev. 1997, 40, 39-58. [CrossRef]

15. Csikszentmihalyi, M. Society, culture, and person: A systems view of creativity. In The Nature of Creativity: Contemporary Psychological Perspectives; Sternberg, R., Ed.; Cambridge University Press: Cambridge, UK, 1988; pp. 325-339.

16. Csikszentmihalyi, M. Creativity. Flow and the Psychology of Discovery and Invention; HarperCollins: New York, NY, USA, 1997.

17. Sherringham, K.; Unhelkar, B. Crafting and Shaping Knowledge Worker Services in the Information Economy; Palgrave Macmillan: Singapore, 2020.

18. Figurska, I. The Concept of a Comprehensive Approach to Knowledge Management in the Organization; CeDeWu Publishing: Warsaw, Poland, 2019.

19. Cortada, J. Rise of the Knowledge Worker; Routledge: New York, NY, USA, 2017.

20. Turriago-Hoyos, A.; Thoene, U.; Arjoon, S. Knowledge workers and virtues in Peter Drucker's management theory. SAGE Open 2016, 6, 1-9. [CrossRef]

21. Wilson, C. Are All Workers Knowledge Workers? New Economy Knowledge Workers-Part 1; Michigan State University Extension: East Lansing, MI, USA, 2017. Available online: https://www.canr.msu.edu/news/are_all_workers_knowledge_worker_new_ economy_knowledge_worker_part_1 (accessed on 10 July 2020).

22. Wright, M.; Tartari, V.; Huang, K.G.-L.; Di Lorenzo, F.; Bercovitz, J. Knowledge Worker Mobility in Context: Pushing the Boundaries of Theory and Methods. J. Manag. Stud. 2018, 55, 1-26. [CrossRef]

23. Gaizauskiene, L.; Tunčikienè, Ž. The concept and role of knowledge worker and workplace fit in learning organisation. Int. J. Learn. Chang. 2016, 8, 245-260. [CrossRef] 
24. Nickols, F. Drucker's Dictums: Knowledge Work, Workers \& Working. 2016. Available online: https://www.nickols.us/ DruckersDictums.pdf (accessed on 10 January 2021).

25. Sobocka-Szczapa, H. Acquiring knowledge workers in organizations. Ekon. I Prawo. Econ. Law 2020, 19, 119-134. [CrossRef]

26. Choi, J.N.; Anderson, T.A.; Veillette, A. Conceptual inhibitors of employee creativity in organizations: The insulating role of creative ability. Group Organ. Manag. 2009, 34, 330-357. [CrossRef]

27. Shin, S.J.; Kim, T.-Y.; Lee, J.-Y.; Bian, L. Cognitive Team diversity and individual team member creativity: A cross-level interaction. Acad. Manag. J. 2012, 55, 197-212. [CrossRef]

28. Bratnicka-Myśliwiec, K. Bogactwo Społeczno-Emocjonalne i Twórczość Organizacyjna w Przedsiębiorstwie; Wydawnictwo Uniwersytetu Ekonomicznego w Katowicach: Katowice, Poland, 2019.

29. Sirkova, M.; Ali Taha, V.; Ferencova, M. An analytical study on organizational creativity: Implications for management. Pol. J. Manag. Stud. 2014, 10, 179-218.

30. Amabile, T.M.; Barsade, S.G.; Mueller, J.S.; Staw, B.M. Affect and Creativity at Work. Adm. Sci. Q. 2005, 50, 367-403. [CrossRef]

31. Johnson, A.P. Education Psychology: Theories of Learning and Human Development; National Science Press: EL Cajon, CA, USA, 2014; Available online: www.nsspress.com (accessed on 22 April 2021).

32. Sternberg, R. Retracted article: The Nature of Creativity. Creativity Res. J. 2006, 18, 87-98. [CrossRef]

33. Esra, S. Creativity and the importance of business management. Int. J. Sci. Eng. Res. 2017, 8, 428-439.

34. Blomberg, A. Organizational Creativity-Hegemonic and Alternative Discourses. Turku School of Economics. 2016. Series A. Available online: https:/ / www.utupub.fi/bitstream/handle/10024/119889/Ae1_2016.pdf?sequence=2\&isAllowed=y (accessed on 29 April 2021).

35. Kao, J. Entrepreneurship, Creativity and Organization; Prentice Hall International Limited: London, UK, 1989.

36. Csikszentmihalyi, M. Flow: The psychology of optimal experience. J. Leis. Res. 1990, 24, 93-94. [CrossRef]

37. Oldham, G.R.; Cummings, A. Employee creativity: Personal and contextual factors at work. Acad. Manag. J. 1996, 39, 607-634. [CrossRef]

38. Sternberg, R.J.; Lubart, T.I. The concept of creativity: Prospects and paradigms. In Handbook of Creativity; Sternberg, R.J., Ed.; Cambridge University Press: Cambridge, UK, 1999; pp. 3-15.

39. Ford, C.M.; Gioia, D.A. Factors influencing creativity in the domain of managerial decision making. J. Manag. 2000, 26, 705-732. [CrossRef]

40. Zhou, J.; George, J.M. when job dissatisfaction leads to creativity: Encouraging the expression of voice. Acad. Manag. J. 2001, 44, 682-696. [CrossRef]

41. Martins, E.; Terblanche, F. Building organisational culture that stimulates creativity and innovation. Eur. J. Innov. Manag. 2003, 6, 64-74. [CrossRef]

42. Choi, W.; Madjar, N.; Yun, Y. Perceived organizational support, goal orientation, Exchange ideology and creativity. In Proceedings of the Academy of Management, Montreal, QC, Canada, 6-10 August 2010.

43. Munfard, M.D.; Robledo, I.C.; Hester, K.S. Creativity, innovation, and leadership: Models and findings. In The Sage Handbook of Leadership; Bryman, A., Collinson, D., Grint, K., Jackson, B., Uhl-Bien, M., Eds.; Sage: Los Angeles, CA, USA; London, UK; New Delhi, India; Singapore; Washington, DC, USA, 2011; pp. 405-421.

44. Basadur, M.; Basadur, T.; Licina, G. Organizational Development. In Handbook of Organizational Creativity; Mumford, M.D., Ed.; Academic Press/Elsevier: London, UK; Waltham, MA, USA; San Diego, CA, USA, 2012; pp. 667-703.

45. Zhou, J.; Ren, R. Striving for creativity. Building positive contexts in the workplace. In The Oxford Handbook of Positive Scholarship; Cameron, K.S., Spreitzer, G.M., Eds.; Oxford University Press: New York, NY, USA, 2012; pp. 97-109.

46. Bratnicka-Myśliwiec, K. Creativity and effectiveness in organizations. A new approach to an old question. Management 2015, 19, 33-45. [CrossRef]

47. Cook, J.; Wall, T. New work attitude measures of trust, organizational commitment and personal need non-fulfilment. J. Occup. Psychol. 1980, 53, 39-52. [CrossRef]

48. Nonaka, I.; Takeuchi, H. The Knowledge-Creating Company: How Japanese Companies Create the Dynamics of Innovation; Oxford University Press: New York, NY, USA, 1995.

49. Gurteen, D. Knowledge, Creativity and Innovation. J. Knowl. Manag. 1998, 2, 5-13. [CrossRef]

50. Andriopoulos, C.; Lowe, A. Enhancing organisational creativity: The process of perpetual challenging. Manag. Decis. 2000, 38, 734-742. [CrossRef]

51. Amar, A.D.; A Juneja, J. A descriptive model of innovation and creativity in organizations: A synthesis of research and practice. Knowl. Manag. Res. Pr. 2011, 6, 298-311. [CrossRef]

52. Franková, E. Kreativita a Inovace v Organizaci; Grada: Praha, Czech Republic, 2011.

53. Ma, Y.; Cheng, W.; Ribbens, B.A.; Zhou, J. Linking ethical leadership to employee creativity: Knowledge sharing and self-efficacy as mediators. Soc. Behav. Pers. Int. J. 2013, 41, 1409-1419. [CrossRef]

54. Figurska, I.; Sokół, A. Empirical verification of knowledge management initiatives as determinants of the development of knowledge workers' creativity. In Vision 2025: Education Excellence and Management of Innovations through Sustainable Economic Competitive Advantage, Proceedings of the 34th International Business Information Management Association Conference (IBIMA), Madrid, Spain, 13-14 November 2014; Soliman, K.S., Ed.; Curran Associates, Inc.: Red Hook, NY, USA, 2019; pp. $9834-9845$. 
55. Choi, H.-S.; Thompson, L. Old wine in a new bottle: Impact of membership change on group creativity. Organ. Behav. Hum. Decis. Process. 2005, 98, 121-132. [CrossRef]

56. Cohen, W.M.; Levinthal, D. Absorptive capacity: A new perspective on learning and innovation. Adm. Sci. Q. 1990, 35, 128. [CrossRef]

57. Davenport, T.H. Thinking for a Living: How to Get Better Performance and Results from Knowledge Workers; Harvard Business School Press: Boston, MA, USA, 2005.

58. Drucker, P.F. Landmarks of Tomorrow; Harper \& Brothers Publishers: New York, NY, USA, 1957.

59. Nickols, F. The Shift from Manual Work to Knowledge Work; Distance Consulting LLC: Bellevue, WA, USA, 2012. Available online: http:/ / www.nickols.us/shift_to_KW.htm (accessed on 10 January 2021).

60. Gurteen, D. The Gurteen perspective: Taking responsibility. Inside Knowl. Mag. 2006, 10, 1-2.

61. Morawski, M. Problematyka zarządzania pracownikami wiedzy. Przegląd Organ. 2003, 1, 17-20. [CrossRef]

62. Skrzypek, E. Kreatywność pracowników wiedzy i ich wpływ na innowacyjność przedsiębiorstw. In Kapitat Intelektualny i Jego ochrona; Okoń-Horodyńska, E., Wisła, R., Eds.; Instytut Wiedzy i Innowacji: Warszawa, Poland, 2009.

63. Morello, D.; Caldwell, F. What Are Knowledge Workers? What Makes Them Thick? Gartner Group Research: Stamford, CO, USA, 2001; Note SPA-12-7780.

64. Serrat, O. Managing Knowledge Workers, Knowledge Solutions 2008, No 2. Available online: file:///C:/Users/neonet/ AppData/Local/Temp/ManagingKnowledgeWorkers-1.pdf (accessed on 14 October 2020).

65. Nicholas, A.J. Motivational Factors of Telework. In Advanced Methodologies and Technologies in Business Operations and Management; Khosrow-Pour, M., Ed.; IGI Global: Hershey, NY, USA, 2019; pp. 350-365.

66. Rosenthal-Sabroux, C.; Grundstein, M.; Iafrate, F. A Knowledge Worker Desktop Model (KWDM) Applied to Decision Support System. In Encyclopedia of Decision Making and Decision Support Technologies; Adam, F., Humphreys, P., Eds.; IGI Global: Hershey, NY, USA, 2008; pp. 584-592.

67. Competencies for the Knowledge Economy, OECD. Available online: https://www.oecd.org/innovation/research/1842070.pdf (accessed on 12 April 2021).

68. Surawski, B. Who is a "knowledge worker"-Clarifying the meaning of the term through comparison with synonymous and associated terms. Management 2019, 23, 105-133. [CrossRef]

69. Sveiby, K.E. The New Organisational Wealth: Managing and Measuring Knowledge-Based Assests; Berrett-Koehler Publishers: San Francisco, CA, USA, 1997.

70. Alvesson, M. Management of Knowledge Intensive Companies; De Gruyter: Berlin, Germany, 1995.

71. Toffler, A. Powershift: Knowledge, Wealth and Violence at the Edge of the 21st Century; Bantam Books: New York, NY, USA, 1990.

72. Reich, R.B. The Work of Nations; Vintage Books: New York, NY, USA, 1992.

73. Kidd, A. The marks are on the knowledge worker. In Proceedings of the SIGCHI Conference on Human Factors in Computing Systems, Boston, MA, USA, 24-28 April 1994; pp. 186-191. [CrossRef]

74. Armstrong, M. A Handbook of Human Resource Management Practice; Cambridge University Press: Cambridge, UK, 2006.

75. Hlupic, V.; Pouloudi, A.; Rzevski, G. Towards an integrated approach to knowledge management: 'hard', 'soft' and 'abstract' issues. Knowl. Process. Manag. 2002, 9, 90-102. [CrossRef]

76. Maier, R.; Remus, U. Implementing process-oriented knowledge management strategies. J. Knowl. Manag. 2003, 7, 62-74. [CrossRef]

77. Rutheford, A.; Tait, J.A. Knowledge Management Implementation Trends; kBOS; 2004; pp. 4-5.

78. Sveiby, K.E. What Is Knowledge Management? 2001. Available online: https://www.sveiby.com/files/pdf/ whatisknowledgemanagement.pdf (accessed on 10 April 2020).

79. Figurska, I. Personal aspects of knowledge management. In Managing Diversity in the Organization. Creativity-KnowledgeCompetence—Innovation - Trust; Sokół, A., Ed.; Sciemcee Publishing: London, UK, 2015.

80. Kropsu-Vehkapera, H.; Isoherranen, V. Lean approach in knowledge work. J. Ind. Eng. Manag. 2018, 11, 429-444. [CrossRef]

81. Bernstein, M. Knowledge Work 2020. The Future of Knowledge Work and What it Might Mean to Each of You, CEO. PARC, XEROX Summit 2010. Available online: http://download.microsoft.com/ /Mark\%20Bernstein\%20Xerox\%20Summit (accessed on 10 May 2021).

82. Probst, G.; Raub, S.; Romhardt, K. Zarządzanie Wiedza w Organizacji; Oficyna Ekonomiczna: Kraków, Poland, 2002.

83. Ceptureanu, S.I.; Ceptureanu, E.G.; Olaru, M.; Popescu, D.I. An exploratory study on knowledge management process barriers in the oil industry. Energies 2018, 11, 1977. [CrossRef]

84. Blaskova, M.; Grazulis, V. Motivation of Human Potential: Theory and Practice; Mykolas Romeris University, Zilina University: Vilnius, Lithuania, 2009.

85. Polanyi, M. The Tacit Dimension; Garden City: New York, NY, USA, 1966.

86. De Jong, T.; Ferguson-Hessler, M.G. Types and qualities of knowledge. Educ. Psychol. 1996, 31, 105-113. [CrossRef]

87. Głuszek, E. Zarzadzanie Zasobami Niematerialnymi Przedsiębiorstwa; Wydawnictwo Akademii Ekonomicznej im. O. Langego: Wrocław, Poland, 2004.

88. Lundvall, B.; Johnson, B.H. The learning economy. J. Ind. Stud. 1994, 1, 23-42. [CrossRef]

89. Tiwana, A. The Essential Guide to Knowledge Management: E-Business and CRM Applications; Prentice Hall: New York, NY, USA, 2000. 
90. Figurska, I.; Sokol, A. Potential of creative knowledge of workers and their development in a sustainable organisation. Eur. Res. Stud. J. 2020, XXIII, 628-650. [CrossRef]

91. Figurska, I.; Sokół, A. Organizational work environment and creativity of knowledge workers-Selected aspects. In Proceedings of the 35th International Business Information Management Association Conference (IBIMA), Seville, Spain, 1-2 April 2020; pp. 1853-1864.

92. Sokół, A.; Figurska, I. Creativity as one of the core competencies of studying knowledge workers. Entrep. Sustain. Issues 2017, 5, 23-35. [CrossRef]

93. Sokol, A.; Gozdek, A.; Figurska, I.; Blaskova, M. Organizational climate of higher education institutions and its implications for the development of creativity. Procedia Soc. Behav. Sci. 2015, 182, 279-288. [CrossRef]

94. Sokol, A.; Gozdek, A.; Figurska, I. The importance of teacher leadership in shaping the creative attitudes of students. Procedia Soc. Behav. Sci. 2015, 197, 1976-1982. [CrossRef]

95. Barron, F.; Harrington, D.M. Creativity, intelligence, and personality. Annu. Rev. Psychol. 1981, 32, 439-476. [CrossRef]

96. Mackinnon, D.W. Personality and the realization of creative potential. Am. Psychol. 1965, 20, 273-281. [CrossRef] [PubMed]

97. Csikszentmihalyi, M. Implications of a systems perspective for the study of creativity. In Handbook of Creativity; Sternberg, R.J., Ed.; Cambridge University Press: Cambridge, UK, 1999; pp. 313-335.

98. Dobrołowicz, W. Psychologia Twórczości Technicznej; WNTFKNT: Warsaw, Poland, 1993.

99. Dudek, S.Z.; Hall, W.B. Personality consistency: Eminent architects 25 years later. Creativity Res. J. 1992, 4, 213-231. [CrossRef]

100. Gardner, H.; Wolf, C. The fruits of asynchrony: A psychological examination of creativity. In Changing the World: A Framework for the Study of Creativity; Feldman, D.H., Csikszentmihalyi, M., Gardner, H., Eds.; Praeger: Westport, CT, USA, $1994 ;$ pp. 47-68.

101. Guilford, J.P.; Hoepfner, R. The Analysis of Intelligence; McGraw-Hill: New York, NY, USA, 1971.

102. Helson, R. A Longitudinal Study of Creative Personality in Women. Creativity Res. J. 1999, 12, 89-101. [CrossRef]

103. Peszko, K.; Sokół, A. Twórczość i Kreatywność w Mediach Reklamowych-Ujęcie Teoretyczne i Empiryczne; Volumina: Szczecin, Poland, 2016.

104. Khalil, H.K. Nonlinear Systems; Prentice Hall: Upper Saddle River, NJ, USA, 1996.

105. Sternberg, R.J.; O’Hara, L.A.; Lubart, T.I. Creativity as investment. Calif. Manag. Rev. 1997, 40, 8-21. [CrossRef]

106. Shalley, C.E.; Zhou, J.; Oldham, G.R. The effects of personal and contextual characteristics on creativity: Where should we go from here? J. Manag. 2004, 30, 933-958. [CrossRef]

107. Kaufman, J.C. Kreatywność; APS: Warsaw, Poland, 2011.

108. Guilford, J.P. Creativity. Am. Psychol. 1950, 5, 444-454. [CrossRef]

109. Torrance, E.P. The Torrance Tests of Creative Thinking-Norms-Technical Manual Research Edition-Verbal Tests, Forms A and B-Figural Tests, Forms A and B; Personnel Press: Princeton, NJ, USA, 1974.

110. Kirton, M. Adaptors and innovators: A description and measure. J. Appl. Psychol. 1976, 61, 622-629. [CrossRef]

111. Filipczak, B. It takes all kinds: Creativity in the work force. Training 1997, 34, 32-40.

112. Bresnahan, T.F. Computerization and Wage Dispersion: An Analytical Reinterpretation; Working Paper; Stanford University: Stanford, CA, USA, 1997; 39p. [CrossRef]

113. De Jong, J.; Hartog, D.D. Measuring Innovative Work Behaviour. Creativity Innov. Manag. 2010, 19, 23-36. [CrossRef]

114. Roffe, I. Innovation and creativity in organisations: A review of the implications for training and development. J. Eur. Ind. Train. 1999, 23, 224-241. [CrossRef]

115. Williams, M. Problems of Knowledge. A Critical Introduction to Epistemology; OUP: Oxford, UK, 2001.

116. Dutton, G. Enhancing creativity. Manag. Rev. 1996, 85, 44.

117. Ekvall, G. Organizational climate for creativity and innovation. Eur. J. Work. Organ. Psychol. 1996, 5, 105-123. [CrossRef]

118. Amabile, T.M. How to kill creativity. Harv. Bus. Rev. 1998, 76, 76.

119. Dacey, J.S.; Lennon, K.H. Kreativita; Grada: Prague, Czech Republic, 2000.

120. Walker, A.M.; Koestner, R.; Hum, A. Personality Correlates of Depressive Style in Autobiographies of Creative Achievers. J. Creative Behav. 1995, 29, 75-94. [CrossRef]

121. Wolfradt, U.; Pretz, J.E. Individual differences in creativity: Personality, story writing, and hobbies. Eur. J. Pers. 2001, 15, 297-310. [CrossRef]

122. Kaufman, J.C. Dissecting the Golden Goose: Components of Studying Creative Writers. Creativity Res. J. 2002, 14, 27-40. [CrossRef]

123. Stevenson, C.E.; Kleibeuker, S.W.; De Dreu, C.K.W.; Crone, E.A. Training creative cognition: Adolescence as a flexible period for improving creativity. Front. Hum. Neurosci. 2014, 8. [CrossRef] [PubMed]

124. Ashby, F.G.; Isen, A.M.; Turken, A.U. A neuropsychological theory of positive affect and its influence on cognition. Psychol. Rev. 1999, 106, 529-550. [CrossRef]

125. Scheier, M.F.; Carver, C. Effects of optimism on psychological and physical well-being: Theoretical overview and empirical update. Cogn. Ther. Res. 1992, 16, 201-228. [CrossRef]

126. Davenport, T.H.; Prusak, L. Working Knowledge: How Organizations Manage What They Know; Harvard Business School Press: Boston, MA, USA, 1998.

127. Giampaoli, D.; Ciambotti, M. Knowledge versus creativity: Which of them really matter? In Proceedings of the Conference: Chal-langes of the Knowledge Society-CKS 2016, Bucharest, Romania, 20-21 May 2016. 
128. Gong, Y.; Zhou, J.; Chang, S. Core Knowledge Employee Creativity and Firm Performance: The Moderating Role of Riskiness Orientation, Firm Size, and Realized Absorptive Capacity. Pers. Psychol. 2013, 66, 443-482. [CrossRef]

129. Kogut, B.; Zander, U. Knowledge of the Firm, Combinative Capabilities, and the Replication of Technology. Organ. Sci. 1992, 3, 383-397. [CrossRef]

130. Spender, J.-C.; Grant, R.M. Knowledge and the firm: Overview. Strat. Manag. J. 1996, 17, 5-9. [CrossRef]

131. Mannucci, P.V. How Knowledge Can Stimulate but Also Impede Creativity. 2016. Available online: https://www.hec.edu/en/ knowledge/instants/how-knowledge-can-stimulate-also-impede-creativity (accessed on 29 May 2021). 